\title{
Integrated Environmental Assessment of streams in the Sinos River basin in the state of Rio Grande do Sul, Brazil
}

\author{
Kieling-Rubio, MA. ${ }^{a *}$, Benvenuti, T. ${ }^{b}$, Costa, GM. ${ }^{c, d}$, Petry, CT. ${ }^{c}$, Rodrigues, MAS. , \\ Schmitt, JL. ${ }^{d}$ and Droste, A. ${ }^{d}$ \\ a'Laboratório de Botânica, Universidade Feevale, \\ Rodovia RS-239, 2755, Vila Nova, CEP 93525-075, Novo Hamburgo, RS, Brazil \\ 'Laboratório LACOR/PPGE3M, Universidade Federal do Rio Grande do Sul - UFRGS, \\ Avenida Bento Gonçalves, 9500, Agronomia, CEP 91501-970, Porto Alegre, RS, Brazil \\ 'Laboratório de Biotecnologia Vegetal, Universidade Feevale, \\ Rodovia RS-239, 2755, Vila Nova, CEP 93525-075, Novo Hamburgo, RS, Brazil \\ dPrograma de Pós-Graduação em Qualidade Ambiental, Universidade Feevale, \\ Rodovia RS-239, 2755,Vila Nova, CEP 93525-075, Novo Hamburgo, RS, Brazil \\ *e-mail: angelrubio@ig.com.br
}

Received: May 24, 2013 - Accepted: August 26, 2013 - Distributed: May 31, 2015

(With 1 figure)

\begin{abstract}
The deterioration of environmental quality in the Sinos River basin is directly associated with the impacts of intense industrialization and urbanization. An integrated environmental assessment (IEA) was conducted in July and September of 2012, in areas along the sources of the EstânciaVelha/Portão, Pampa and Schmidt streams using physical, chemical and biological methods. The water in the three sampling sites was not proper for human consumption, presented a low toxic contamination index (TCI) and mesotrophic characteristics. One site was included in Class 4, and two, in Class 3 , according to current legislation. The rapid assessment protocol (RAP) indicated a natural environmental condition for habitat diversity and environmental impact in the three sites. The Tradescantia pallida (Rose) D.R. Hunt var. purpurea Boom biomarker showed water genotoxicity in two of the sites. The integrated diagnosis of water quality in these streams is fundamentally important to ensure the sustainable management of water resources and their multiple uses, as well to estimate their contribution to pollution in this river basin.
\end{abstract}

Keywords: genotoxicity, water quality indices, source, rapid assessment protocol.

\section{Avaliação Ambiental Integrada de arroios da bacia do Rio dos Sinos no Estado do Rio Grande do Sul, Brasil}

\section{Resumo}

A deterioração da qualidade ambiental da bacia do Rio dos Sinos está diretamente associada a impactos oriundos da intensa industrialização e urbanização. A avaliação ambiental integrada (AAI) foi realizada nos meses de julho e setembro de 2012, em áreas junto às nascentes dos arroios Estância Velha/Portão, Pampa e Schmidt por meio de metodologias que utilizam parâmetros físicos, químicos e biológicos. Os três sítios amostrais apresentaram águas impróprias para o consumo humano, baixo índice de contaminação por tóxicos (ICT) e características mesotróficas. Um sítio foi enquadrado na Classe 4 e dois na Classe 3, segundo a legislação vigente. Os resultados da aplicação do protocolo de avaliação rápida (PAR) indicaram uma situação ambiental natural, quanto à diversidade de habitats e aos impactos ambientais, nos três sítios amostrados. O biondicador Tradescantia pallida (Rose) D.R. Hunt var. purpurea Boom evidenciou genotoxicidade da água em dois sítios amostrados. O diagnóstico integrado da qualidade das águas destes arroios é de fundamental importância para assegurar o gerenciamento sustentado dos recursos hídricos e seus múltiplos usos, além de estimar sua contribuição à poluição desta bacia hidrográfica.

Palavras-chave: genotoxicidade, índices de qualidade da água, nascente, protocolo de avaliação rápida.

\section{Introduction}

Water bodies and the community of living organisms in these ecosystems are recognized as fundamentally important for different sectors of our society, despite the evident and substantial growth of environmental impacts. They are highly susceptible to environmental changes due to their interactions with surroundings (Ternus et al., 2011). 
The Sinos River basin (SRB) is located in the eastern region of the state of Rio Grande do Sul, Brazil, and covers 32 towns with different economic activities, such as industry, agriculture and cattle raising, along the 190 $\mathrm{km}$ of the Sinos River, one of the main water courses in the basin and the river with the poorest water quality in Brazil (Figueiredo et al., 2010). Among the main affluents of the Sinos River are the EstânciaVelha/Portão (municipalities of Estância Velha and Portão), the Pampa (municipality of Novo Hamburgo) and the Schmidt (municipality of Campo Bom) streams, located in the lower section of the basin and draining important urban centres in the metropolitan area of Porto Alegre. Their sources or surroundings are located in an important industrial centre, a national reference in the production and exportation of footwear and leather (IBGE, 2012). Parallel to the rapid economic growth of these cities in the last decades, environmental problems have been generated due to the indiscriminate use of water, disorganised land occupation, lack of basic sanitation and, mainly, concentration of industrial activities that have a high polluting potential.

Environmental changes resulting from the growth and economic development of the towns have a significant impact on these streams. The Pampa stream presents high levels of domestic pollution along its course, often comparable to untreated domestic wastewaters (Nascimento and Naime, 2009), and the contamination of the EstânciaVelha/Portão stream has been assigned to domestic and industrial wastewater discharges (Naime and Fagundes, 2005).

The concern with the status of environmental degradation demands efficient evaluation methods and tools for environmental management (Rodrigues and Castro, 2008). Rivers are usually monitored by means of physical, chemical and bacteriological tests to determine water quality for human use (Rodrigues et al., 2008) following the parameters defined in the CONAMA Resolution no. 375/2005 (Brasil, 2005). However, these parameters, when analysed individually, may underestimate the actual magnitude of damage caused to water environments (Karr and Chu, 1999). Therefore, rapid assessment protocols (RAP) have been developed to evaluate the structure and functioning of water ecosystems and contribute to the management and preservation of these environments using parameters that are easy to understand and apply (Callisto et al., 2002).

Bioindicator plants are highly sensitive to complex mixtures of water contaminants and may be used for qualitative evaluations of genetic damage to living organisms (Duan et al., 1999; Grisolia and Starling, 2001; Merlo et al., 2011). Tradescantia pallida (Rose) D.R. Hunt var. purpurea Boom, a wild species that is well adapted to subtropical and tropical climates, has a high sensitivity to genotoxic agents and has been used to monitor water bodies and domestic wastewaters (Umbuzeiro et al., 2007; Mielli et al., 2009; Thewes et al., 2011).

A study in the Sinos River basin assessed the genotoxicity of water through the comet assay in fish, showing that in this environment there are substances with genotoxic potential on these organisms (Scalon et al., 2010). Other studies have also indicated water toxicity in the Sinos River. Rechenmacher et al. (2010) observed hepatotoxic effects in cells from mice exposed to samples of the river water. Feiden and Terra (2009) used Daphnia magna (Strauss, 1920) to assess the quality of water by toxicity tests.

Integrated methods should be used to evaluate environmental impacts generated by the inappropriate use and management of water resources. This study represents the first initiative of an integrated evaluation of environmental quality along the sources of the EstânciaVelha/Portão, Pampa and Schmidt streams using physical, chemical and biological parameters. The data may contribute for an integrated environmental diagnosis of the Sinos River basin, supporting public management and providing reliable bases and methods for environmental control.

\section{Material and Methods}

\subsection{Study area}

The major watercourse of the Sinos River basin is located in the northeastern area of the state of Rio Grande do Sul (29 $\left.20^{\prime}-30^{\circ} 10^{\prime} \mathrm{S} ; 50^{\circ} 15^{\prime}-51^{\circ} 20^{\prime} \mathrm{W}\right)$ (FEPAM, 2012). The total area basin measures $3,820 \mathrm{~km}^{2}$, and it extends from the Serra Geral in the East, to the Caí River basin in the West and the North, and to the Gravataí River basin in the South (COMITESINOS, 2012). The basin vegetation cover is reduced to forest remains, predominantly at the sources of the Sinos River and the streams that form it. For hydrological and hydraulic classifications, the Sinos River has been divided into upper, middle and lower sections. The ground in the region is formed by dystrophic red clay soils originated from sandstone that was part of the Botucatu formation (Streck et al., 2008). The lower section has semideciduous seasonal forest remains (Teixeira et al., 1986), gentle to no slopes and counter-sloping areas characteristic of plain rivers, meanders and has sedimentation zones (FEPAM, 2012). The climate of the study area is Cfa according to the Köppen classification (Moreno, 1961); the mean annual temperature is about $20^{\circ} \mathrm{C}$, and rainfall is about $1,600 \mathrm{~mm}$ per year, distributed in four seasons (COMITESINOS, 2012).

\subsection{Study sites}

The integrated environmental assessment was performed in the sources of the three streams in the lower section of the Sinos River (Figure 1). Site 1 (29 38'17.06'S and 51 9'17.09”'W; at 67 m a.s.1.): EstânciaVelha/Portão stream, located in EstânciaVelha and Portão and about $20 \mathrm{~km}$ long. Site 2 (29 $38^{\prime} 28.5^{\prime \prime} \mathrm{S}$ and $51^{\circ} 06^{\prime} 39.51^{\prime \prime} \mathrm{W}$; at $153 \mathrm{~m}$ a.s.1.): Pampa stream, located in Novo Hamburgo and about 9 $\mathrm{km}$ long. Site $3\left(29^{\circ} 39^{\prime} 6.64^{\prime \prime} \mathrm{S}\right.$ and $51^{\circ} 4^{\prime} 51.23^{\prime \prime} \mathrm{W}$; at $52 \mathrm{~m}$ a.s.1.): Schmidt stream, located in Campo Bom and about $7 \mathrm{~km}$ long. These sites are located in a lithological area characterized by the Botucatu Formation and basaltic formations in the hillsides (Streck et al., 2008). The sites were sampled in July and September of 2012. Local data on rainfall were supplied by Station no. 83961, the weather 


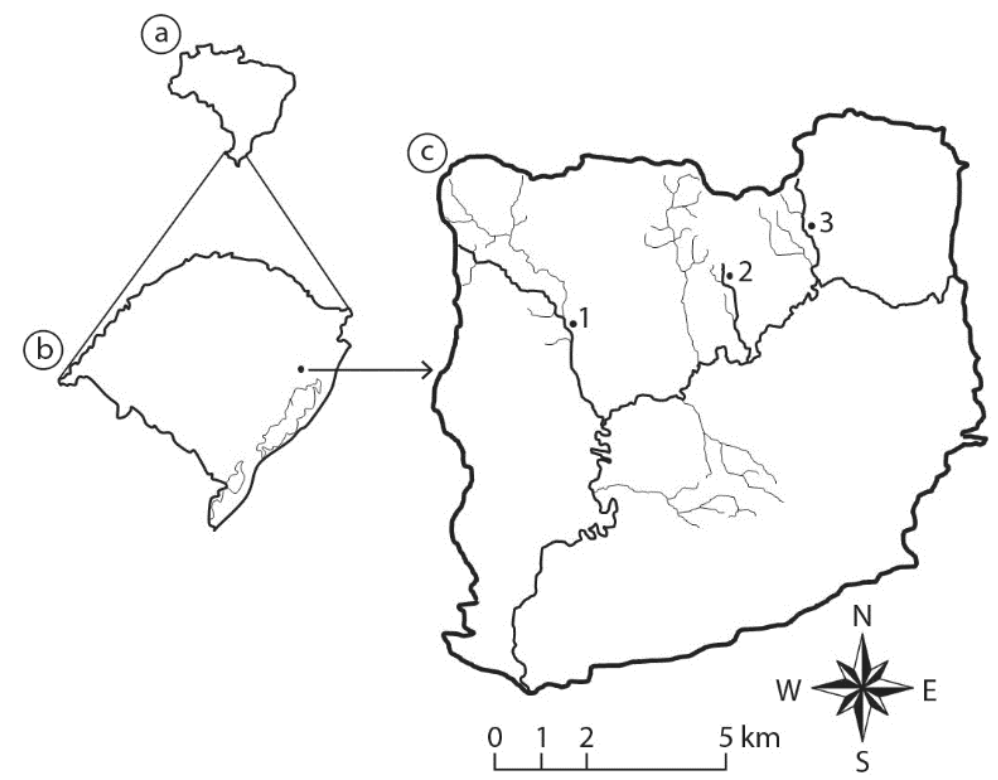

Figure 1. Location of the study sites (c) of the integrated environmental assessment in the Sinos River basin, state of Rio Grande do Sul (b), Brazil (a): Estância Velha/Portão stream (1); Pampa stream (2) and Schmidt stream (3).

station closest to the sampling site in Campo Bom (294 'S; $\left.51^{\circ} 03^{\prime} \mathrm{W}\right)$, at an altitude of $25.8 \mathrm{~m}$. Sampling sites and the weather station are located in areas under similar weather conditions (Buriol et al., 2007).

\subsection{Physical, chemical and microbiological analyses}

In each study site $\mathrm{pH}$, dissolved oxygen concentration and percentage, temperature, total dissolved solids and conductivity of the water were monitored in situ. Measurements were made with portable multiparameter units (YSI ADV6600 A2, SonTek). Water samples were collected and stored following the recommendations of the Brazilian Association of Technical Norms (ABNT, 1987) and Standard Methods for the Examination of Water and Wastewater (APHA, 2005).

The parameters analysed were: a) total alkalinity by titrimetry; b) total phosphorus by colorimetry; c) dissolved oxygen by manometry; d) microbial sewage pollution indicators (fecal coliforms and Escherichia coli (Escherich, 1885)) using an enzymatic substrate method; e) $\mathrm{Cr}(\mathrm{VI})$ by colorimetry; f) chloride by titrimetry; g) ammonia by titrimetry; $\mathrm{h}$ ) nitrite by colorimetry and i) nitrate concentration by colorimetry. In addition, cadmium, lead, copper, total chrome, iron, manganese, nickel and zinc concentrations were measured by flame atomic absorption spectroscopy (FAAS) in all water samples collected.

\subsubsection{Freshwater classification}

The water bodies were classified according to the limits for freshwater classes defined in Resolution 357/2005 of the National Environment Council (CONAMA) (Brasil, 2005) which define maximum standards for waters according to their uses.

\subsubsection{Water Quality Indices (WQI)}

Two indices (WQI) to assess surface water quality in the river sources were used: the toxic contamination index (TCI) and the trophic state index (TSI).

The toxic contamination index (TCI) used by IGAM (2004), was defined according to the comparison between the results of sample analysis and the limits established for water classes in the Brazilian legislation, CONAMA Resolution 357/2005 (Brasil, 2005) for: ammonia, cadmium, lead, total copper, chrome (VI), total chrome, nitrate, nitrite and total zinc. According to Brasil (2012), TCI may be low, medium or high. If low, toxic substances have concentrations lower than or equal to $20 \%$ of the classification limits. In the medium class, concentrations are $20 \%$ to $100 \%$ of those limits, and in the high class, greater than $100 \%$. The worst result in the set of all values is used to define the contamination category. Therefore, if one of the parameters was greater than $100 \%$ (twice the limit concentration) in at least one of the yearly measurements, contamination was classified as high at that sampling site.

The trophic state index (TSI) indicates the quality of water according to its enrichment with nutrients and its effect associated with the excessive growth of algae or the increase in the infestation with aquatic macrophytes. The results of this index calculated from phosphorus values are a measure of potential river eutrophy, according to Lamparelli (2004) and Fia et al. (2009), as the equation $\mathrm{TSI}=10[6-((0.42-0.36(\ln \mathrm{TP})) / \ln 2)]-20$, where total phosphorus (TP) is presented in $\mu \mathrm{g} \mathrm{L}^{-1}$.

The categories of the trophic state are: ultra-oligotrophic (TSI $\leq 47)$, oligotrophic (low productivity) $(47<\mathrm{TSI} \leq 52)$, mesotrophic (moderate productivity) $(52<\mathrm{TSI} \leq 59)$, eutrophic (high productivity) $(59<\mathrm{TSI} \leq 63)$, supereutrophic 
Table 1. Results of the rapid assessment protocol (RAP) in three areas at the sources of the EstânciaVelha/Portão, Pampa and Schmidt streams.

\begin{tabular}{|c|c|c|c|}
\hline Parameters/Streams & $\begin{array}{c}\text { EstânciaVelha/ } \\
\text { Portão }\end{array}$ & Pampa & Schmidt \\
\hline 1. Water body margin occupation ${ }^{1}$ & 4 & 4 & 4 \\
\hline 2. Anthropic changes ${ }^{1}$ & 4 & 2 & 2 \\
\hline 3. Vegetal coverage of water bed ${ }^{1}$ & 4 & 4 & 4 \\
\hline 4. Water odor ${ }^{1}$ & 4 & 4 & 4 \\
\hline 5.Water oiliness ${ }^{1}$ & 4 & 4 & 4 \\
\hline 6. Water transparency ${ }^{1}$ & 4 & 4 & 4 \\
\hline 7. Sediment odour (bottom) ${ }^{1}$ & 4 & 4 & 4 \\
\hline 8. Bottom oiliness ${ }^{1}$ & 4 & 4 & 4 \\
\hline 9. Types of bottom ${ }^{1}$ & 3 & 5 & 3 \\
\hline 10. Types of substrate ${ }^{2}$ & 2 & 3 & 3 \\
\hline 11. Mud deposition ${ }^{2}$ & 3 & 5 & 3 \\
\hline 12. Changes in stream bed ${ }^{2}$ & 5 & 5 & 5 \\
\hline 13. Margin stability ${ }^{2}$ & 3 & 5 & 3 \\
\hline 14. Riparian forest length ${ }^{2}$ & 3 & 5 & 3 \\
\hline 15. Aquatic plants ${ }^{2}$ & 5 & 5 & 3 \\
\hline Total score & 56 & 63 & 53 \\
\hline Evaluation & Suboptimal & Optimal & Suboptimal \\
\hline
\end{tabular}

${ }^{1}$ scores 0 (maximal impact), 2 and 4 (minimal impact). ${ }^{2}$ scores 0 (maximal impact), 2, 3 and 5 (minimal impact).

$(63<\mathrm{TSI} \leq 67)$ and hypereutrophic (very high productivity) (TSI > 67) (Alves et al., 2012).

\subsection{Rapid assessment protocol (RAP)}

In each study site, the rapid assessment protocol (RAP) for habitat diversity (EPA, 1987, Hannaford et al., 1997) modified by Callisto et al. (2002) was used to analyze 15 parameters (Table 1). In the first group, the score assigned to each parameter was 0,2 and 4, and in the second, 0,2, 3 or 5 points. The final result was the sum of the scores assigned to each parameter. Final scores indicate the level of ecological preservation of the sites under study, scores from 0 to 20 indicate that the sites has been poor; from 21 to 41, regular; from 42 to 60 , suboptimal and from 61 to 88 , in optimal condition.

\subsection{Tradescantia bioassay}

Water samples from the three sampling points were collected for genotoxicity analysis. Water collection and transportation followed the recommendations of the Brazilian Association of Technical Norms (ABNT, 1987) and Standard Methods for the Examination of Water and Wastewater (APHA, 2005). Samples of Tradescantia pallida var. purpurea were grown in pots $(37 \mathrm{~cm} \times 20 \mathrm{~cm} \times 20 \mathrm{~cm})$ containing $4 \mathrm{~kg}$ of commercial soil from the same batch, in a non-polluted area of the university. The plants were watered three times a week. Monthly, $100 \mathrm{~mL}$ of an N-P-K fertilizer solution (10-10-10, w/w/w) was applied. Plant exposure, inflorescence fixation and storage, slide preparation and data analysis followed the protocol described by Thewes et al. (2011). Cuttings collected from the plant stocks bearing young inflorescences were maintained partially immersed in distilled water for 24 hours in groups of 15 to 20 . After this adaptation, only turgid cuttings were exposed, for 8 hours, to the water samples and to distilled water (negative control). Exposure was followed by a 24 -h recovery period in distilled water. The inflorescences were fixed in 3:1 (v/v) ethanol/acetic acid for $24 \mathrm{~h}$ and stored in $70 \%$ ethanol under refrigeration. Seven slides were prepared for each sample. Micronuclei frequencies were analyzed using the SPSS 20 for Windows. Data were expressed as mean \pm standard deviation. The normal distribution of variables was verified by the Shapiro-Wilk test. Statistical differences in micronuclei frequencies obtained in each sampling point along time were analyzed using the Student $t$ test, at 5\% probability. Frequencies of micronuclei obtained in the samples in each month were compared using ANOVA test. The Tukey test was used for post-hoc multiple comparisons, at $5 \%$ probability.

\section{Results}

\subsection{Physical, chemical and microbiological characteristics of water}

The values of the physical, chemical and microbiological parameters of the water samples collected in July and September 2012 from the streams under study are shown in Table 2. Most parameters analysed in the three sites were lower than the limits established in the CONAMA Resolution 357/2005 (Brasil, 2005) for Class 1 waters.

The waters of the Pampa stream were classified as Class 3, as a result of the Fe concentrations which were seven-fold higher (maximum of $2.140 \mathrm{mg} \mathrm{L}^{-1}$ in July of 2012) than the legal limits $\left(<0.3 \mathrm{mg} \mathrm{L}^{-1}\right)$ for Class 1 
Table 2. Physical, chemical and microbiological characteristics of the sampling sites of the EstânciaVelha/Portão, Pampa and Schmidt streams.

\begin{tabular}{|c|c|c|c|c|c|c|c|c|c|c|}
\hline \multirow{2}{*}{ Parameters } & \multicolumn{3}{|c|}{$\begin{array}{c}\text { EstânciaVelha/Portão } \\
\text { stream }\end{array}$} & \multicolumn{3}{|c|}{ Pampa stream } & \multicolumn{3}{|c|}{ Schmidt stream } & \multirow{2}{*}{$\begin{array}{c}\text { Standard } \\
\text { (Class 1) } \\
\text { CONAMA } \\
\text { 357/2005 }\end{array}$} \\
\hline & July & September & Mean & July & September & Mean & July & September & Mean & \\
\hline Alkalinity $\left(\mathrm{mg} \mathrm{L}^{-1}\right)$ & 50.10 & 46.20 & 48.15 & 67.60 & 43.40 & 55.50 & 49.50 & 23.80 & 34.65 & $\mathrm{NI}^{\mathrm{a}}$ \\
\hline Total coliforms (MPN $100 \mathrm{~mL}^{-1}$ ) & $3.00 \times 10^{3}$ & $3.20 \times 10^{3}$ & $3.1 \times 10^{3}$ & $2.40 \times 10^{2}$ & $1.00 \times 10^{3}$ & $6.20 \times 10^{2}$ & $3.60 \times 10^{4}$ & $2.80 \times 10^{4}$ & $3.2 \times 10^{2}$ & NI \\
\hline $\begin{array}{l}\text { Thermotolerant coliforms } \\
\text { (fecal E. coli) (MPN } 100 \mathrm{~mL}^{-1} \text { ) }\end{array}$ & absent & absent & absent & absent & absent & absent & $2.00 \times 10^{3}$ & $2.00 \times 10^{3}$ & $2.00 \times 10^{3}$ & 200 \\
\hline Chlorides (mg L $\left.{ }^{-1}\right)$ & 3.90 & 3.80 & 3.85 & 2.40 & 6.30 & 4.35 & 5.10 & 1.90 & 3.50 & 250 \\
\hline Conductivity $\left(\mu \mathrm{S} \mathrm{cm}^{-1}\right)$ & 154.25 & 121.05 & 137.65 & 145.50 & 112.40 & 128.95 & 131.25 & 88.10 & 109.68 & NI \\
\hline Colour $(\mathrm{uH})$ & 100.00 & 93.00 & 96.50 & 30.00 & 11.00 & 20.50 & 70.00 & 62.00 & 66.00 & 0 \\
\hline Chromium VI (Cr VI mg L $\left.{ }^{-1}\right)$ & n.d. ${ }^{b}$ & n.d. & n.d. & n.d. & n.d. & n.d. & n.d. & n.d. & n.d. & NI \\
\hline $\mathrm{BOD}_{5}\left(\mathrm{mg} \mathrm{O}_{2} \mathrm{~L}^{-1}\right)$ & $<5.00$ & 6.00 & 5.50 & $<5.00$ & $<5.00$ & $<5.00$ & 8.00 & $<5.00$ & 6.50 & 3.0 \\
\hline $\mathrm{COD}\left(\mathrm{mg} \mathrm{O}_{2} \mathrm{~L}^{-1}\right)$ & 20.20 & 17.80 & 19.00 & 6.40 & 6.00 & 6.20 & 9.50 & 4.00 & 6.75 & NI \\
\hline Hardness $\left(\mathrm{mg} \mathrm{CaCO}_{3} \mathrm{~L}^{-1}\right)$ & 63.00 & 51.00 & 57.00 & 70.50 & 45.00 & 57.75 & 53.50 & 37.50 & 45.50 & NI \\
\hline Total phosphorus $\left(\mathrm{mg} \mathrm{L}^{-1}\right)$ & 0.080 & $<0.012$ & 0.040 & 0.030 & 0.080 & 0.055 & 0.020 & 0.030 & 0.025 & 0.1 \\
\hline Nitrate $\left(\mathrm{mg} \mathrm{L}^{-1}\right)$ & n.e. ${ }^{c}$ & n.d. & n.d. & n.e. & 1.58 & 1.58 & n.e. & 1.35 & 1.35 & 10 \\
\hline Nitrite $\left(\mathrm{mg} \mathrm{L}^{-1}\right)$ & n.e. & 0.019 & 0.02 & n.e. & 0.027 & 0.03 & n.e. & 0.05 & 0.05 & 1 \\
\hline Ammoniacal nitrogen $\left(\mathrm{mg} \mathrm{L}^{-1}\right)$ & n.d. & n.d. & n.d. & n.d. & n.d. & n.d. & n.d. & n.d. & n.d. & $0.5-3.7^{\mathrm{d}}$ \\
\hline Total nitrogen $(\mathrm{Kjeldahl})\left(\mathrm{mg} \mathrm{L}^{-1}\right)$ & 0.55 & 0.78 & 0.67 & 1.75 & 1.96 & 1.86 & 1.10 & 1.76 & 1.43 & NI \\
\hline Oils and fats $\left(\mathrm{mg} \mathrm{L}^{-1}\right)$ & n.e. & 7.10 & 7.10 & n.e. & 0.00 & 0.00 & n.e. & n.d. & 0.00 & 0.0 \\
\hline Dissolved oxygen $\left(\mathrm{mg} \mathrm{L}^{-1}\right)$ & 10.49 & 6.79 & 8.64 & 10.00 & 7.18 & 8.59 & 5.69 & 7.74 & 6.72 & $>6.0$ \\
\hline $\mathrm{pH}$ & 7.15 & 7.30 & 7.23 & 6.48 & 7.03 & 6.76 & 7.53 & 7.03 & 7.28 & 6 to 9 \\
\hline Total dissolved solids $\left(\mathrm{mg} \mathrm{L}^{-1}\right)$ & 189.00 & 101.00 & 145.00 & 232.00 & 160.00 & 196.00 & 151.00 & 156.00 & 153.50 & 500 \\
\hline Total suspended solids $\left(\mathrm{mg} \mathrm{L}^{-1}\right)$ & 28.30 & 12.40 & 20.35 & 7.40 & 2.80 & 5.10 & 13.70 & 14.00 & 13.85 & NI \\
\hline Sulphates (mg L-1) & n.e. & n.d. & n.d. & n.e. & 5.68 & 5.68 & n.e. & n.d. & n.d. & 250 \\
\hline Turbidity (NTU) & n.e. & 41.10 & 41.40 & n.e. & 32.4 & 32.40 & n.e. & 25.20 & 25.20 & 40 \\
\hline Cadmium (Cd mg L $\left.{ }^{-1}\right)$ & n.d. & n.d. & n.d. & n.d. & n.d. & n.d. & 0.002 & n.d. & 0.002 & 0.001 \\
\hline Lead $\left(\mathrm{Pb} \mathrm{mg} \mathrm{L}{ }^{-1}\right)$ & n.d. & n.d. & n.d. & n.e. & n.d. & n.d. & 0.011 & n.d. & 0.011 & 0.01 \\
\hline Copper $\left(\mathrm{Cu} \mathrm{mg} \mathrm{L} \mathrm{L}^{-1}\right)$ & 0.006 & n.d. & 0.006 & 0.005 & 0.003 & 0.004 & n.d. & n.d. & n.d. & 0.009 \\
\hline Total Chromium $\left(\mathrm{mg} \mathrm{L}^{-1}\right)$ & n.d. & n.d. & n.d. & n.d. & n.d. & n.d. & n.d. & n.d. & n.d. & 0.05 \\
\hline Iron $\left(\mathrm{Fe} \mathrm{mg} \mathrm{L} \mathrm{L}^{-1}\right)$ & 2.267 & 1.741 & 2.004 & 2.140 & 1.617 & 1.879 & 0.451 & 1.254 & 0.853 & 0.3 \\
\hline Manganese (Mn mg L ${ }^{-1}$ ) & 0.076 & 0.073 & 0.075 & 0.019 & 0.012 & 0.016 & 0.077 & 0.043 & 0.060 & 0.1 \\
\hline Nickel (Ni mg L ${ }^{-1}$ ) & 0.019 & 0.009 & 0.014 & 0.015 & 0.010 & 0.013 & 0.010 & 0.008 & 0.009 & 0.025 \\
\hline $\operatorname{Zinc}\left(\mathrm{Zn} \mathrm{mg} \mathrm{L} \mathrm{L}^{-1}\right)$ & 0.016 & 0.019 & 0.018 & 0.024 & 0.015 & 0.020 & 0.006 & 0.016 & 0.011 & 0.18 \\
\hline
\end{tabular}

a Not in the resolution. ${ }^{b}$ Not detected. ${ }^{c}$ Not evaluated. ${ }^{d}$ Limit concentration according to the $\mathrm{pH}: 3.7 \mathrm{mg} \mathrm{L}^{-1}$ for $\mathrm{pH} \leq 7.5 ; 2.0 \mathrm{mg} \mathrm{L}{ }^{-1}$ for $7.5<\mathrm{pH}<8.0 ; 1.0 \mathrm{mg} \mathrm{L}^{-1}$ for $8.0<\mathrm{pH}<8.5 ; 0.5 \mathrm{mg} \mathrm{L}^{-1}$ for $\mathrm{pH}>8.5$. Detection limits: Cr VI: $0.00041 \mathrm{mg} \mathrm{L}^{-1}$; nitrate: $0.078503 \mathrm{mg} \mathrm{L}^{-1}$; ammoniacal nitrogen: $0.14 \mathrm{mg} \mathrm{L}^{-1}$; oils and fats: $0.1 \mathrm{mg} \mathrm{L}^{-1}$; sulphates: $0.45 \mathrm{mg} \mathrm{L}^{-1}$; $\mathrm{Cd}: 0.0015 \mathrm{mg} \mathrm{L}-1$; $\mathrm{Pb}: 0.01$ mg L ${ }^{-1}$; $\mathrm{Cu}: 0.0012 \mathrm{mg} \mathrm{L}^{-1}$; total Cr: $0.005 \mathrm{mg} \mathrm{L}^{-1}$.

waters. The Schmidt stream also presented characteristics of Class 3 waters due to high concentrations of thermotolerant coliforms (2,000 MPN $\left.100 \mathrm{~mL}^{-1}\right)$ and of $\mathrm{BOD}_{5}(>3.0 \mathrm{mg}$ $\left.\mathrm{L}^{-1}\right)$. The EstânciaVelha/Portão stream was classified as Class 4 waters, due to high values of color $(>75 \mathrm{uH})$, turbidity $(>40 \mathrm{NTU}), \mathrm{BOD}_{5}\left(>3.0 \mathrm{mg} \mathrm{L}^{-1}\right)$ and oils and fats $\left(>0.0 \mathrm{mg} \mathrm{L}^{-1}\right)$ (Table 2). Class 3 freshwaters may be used for human supply only after conventional or advanced treatment, whereas Class 4 waters may not be intended for human consumption, only for navigation and landscape harmony (Brasil, 2005).

The toxic contamination index (TCI) was low according to the parameters analysed for the three sites, except the level of contamination in the Schmidt stream site, which was medium according to CONAMA Resolution 357/2005 (Brasil, 2005) because of Cd concentration. According to the TSI, the waters in the three sites were classified as mesotrophic (Table 3).

\subsection{Rapid Assessment Protocol (RAP)}

The results of RAP showed that the sites, in general, had a natural environmental condition. The Pampa stream site presented 13 parameters with the highest score, followed by the EstânciaVelha/Portão stream, with 10, and the Schmidt stream, with eight (Table 1).

The parameters with any change in more than one of the sites were type of bottom, type of substrate, mud deposition, margin stability and riparian forest length. In the site of the EstânciaVelha/Portão stream, one of the margins was deforested and used for agriculture, which modified the landscape of the Environmental Preservation Area (EPA) according to Law 4771/1965 (Brasil, 1965) and affected 
parameters such as margin stability, type of bottom, type of substrate and mud deposition in the water body.

Anthropic changes in the sites of the Pampa and Schmidt streams were mainly characterized by the presence of solid residues, such as the disposal of various types of packaging, as well as the discharge of domestic wastewaters in the Schmidt stream.

\subsection{Tradescantia bioassay}

In the first exposure, the frequency of micronuclei of the flower buds exposed to the water sample of the EstânciaVelha/Portão stream were significantly higher than those found in the samples of the Pampa and Schmidt streams and in the negative control (Table 4). In the second exposure, the frequency of micronuclei of the flower buds exposed to the water samples of the Pampa stream were significantly higher than those of the negative control, and the frequency of micronuclei of flower buds exposed to water samples of the EstânciaVelha/Portão and Schmidt streams were intermediate, statistically not differing from those exposed to the samples of the Pampa stream and the negative control. For each exposure, accumulated rainfall four days before and on the day of exposure of Tradescantia pallida var. purpurea cuttings is presented on Table 4.

Table 3. Legal classification and quality index of water at the sampling sites of the EstânciaVelha/Portão, Pampa and Schmidt streams.

\begin{tabular}{lccc}
\hline \multirow{2}{*}{ Parameters } & \multicolumn{3}{c}{ Streams } \\
\cline { 2 - 4 } & $\begin{array}{c}\text { EstânciaVelha/ } \\
\text { Portão }\end{array}$ & Pampa & Schmidt \\
\hline Water class $^{\mathrm{a}}$ & Class 4 & Class 3 & Class 3 \\
TCI $^{\mathrm{b}}$ & Low & Low & Low \\
TSI $^{\mathrm{c}}$ & 54.96 & 56.61 & 52.52 \\
\hline
\end{tabular}

${ }^{a}$ according to CONAMA Resolution 357/2005 (Brasil, 2005).

${ }^{b}$ toxic contamination index. ${ }^{c}$ trophic state index.

\section{Discussion}

This study evaluated different aspects of water quality and habitat diversity in the sources of the streams that form important subsidiary basins of the lower reach of the Sinos River basin. The integration of these data provides support for the environmental diagnosis of the current scenario of the areas under study.

\subsection{Physical, chemical and microbiological characteristics of water}

Sediment transport in the sites under analysis was responsible for the presence of dissolved and suspended solids and, with consequently changes in water colour and turbidity. The presence of suspended materials and the colour of the water reduce transparency, affect esthetics and reduce the luminosity necessary for photosynthesis (Naime and Fagundes, 2005; Luiz et al., 2012; Cunha et al., 2013).

The absence of thermotolerant coliforms (Escherichia coli) in the samples of the Pampa and Estância Velha/Portão streams may be associated with the uneven topography, which makes access difficult and slows urbanization. For the Schmidt stream, where the collection sites are easier to access, the presence of thermotolerant coliforms indicated that there was recent pollution by domestic wastewaters (Merlo et al., 2011). The presence of organic matter as $\mathrm{BOD}_{5}$ and COD may be in part explained by the fact that there is deciduous vegetation in the region.

The high Fe concentration in all the sites may be associated with the presence of this metal in the edaphic profile of the region (Streck et al., 2008). The greatest concentration of metals was found in sediments, favoured by the neutral to alkaline $\mathrm{pH}$ and the presence of organic matter (Merlo et al., 2011; Weber et al., 2013).

The turbidity due the soil leaching and the low volume of water in the studied sites cause the suspension of sediments, contributing to circle nutrients as phosphorus, an important nutrient used to determinate TSI, and also

Table 4. Micronuclei frequency (MCN/100 tetrads) in Tradescantia pallida var. purpurea pollen mother cells exposed for $8 \mathrm{~h}$ to water samples of three streams of the Sinos River basin in comparison with controls and according to rainfall at exposure times.

\begin{tabular}{lcccccc}
\hline \multirow{1}{*}{ Streams } & \multicolumn{2}{c}{$\begin{array}{c}\text { Rainfall }^{1} \\
(\mathbf{m m})\end{array}$} & $\begin{array}{c}\text { MCN } \\
\text { (July) }\end{array}$ & $\begin{array}{c}\text { MCN } \\
\text { (September) }\end{array}$ & T & P \\
\cline { 2 - 5 } & July & September & (mean \pm SD) & (mean \pm SD) & & \\
\hline EstânciaVelha/Portão & 33.8 & 56.7 & $3.85 \pm 1.45 \mathrm{~b}^{*}$ & $2.04 \pm 0,48 \mathrm{ab}$ & 3.127 & 0.016 \\
Pampa & 52.3 & 36.5 & $1.71 \pm 0.70 \mathrm{a}$ & $2.28 \pm 0.62 \mathrm{~b}$ & -1.608 & 0.134 \\
Schmidt & 1.2 & 0.7 & $1.71 \pm 0.40 \mathrm{a}$ & $2.14 \pm 0.32 \mathrm{ab}$ & -2.183 & 0.050 \\
Negative control & & & $2.0 \pm 0.44 \mathrm{a}$ & $1.5 \pm 0.53 \mathrm{a}$ & -1.698 & 0.115 \\
& & & $\mathrm{~F}=9.988$ & $\mathrm{~F}=2.920$ & & \\
\end{tabular}

${ }^{1}$ Accumulated rainfall four days before and on exposure day.

*Asterisk indicates significant difference between means on the same line.

$\mathrm{F}=$ ANOVA test. $\mathrm{P}=$ probability. $\mathrm{SD}=$ standard deviation. Means with different letters in the same column are significantly different according to the Tukey test. 
organic matter, colour and other nutrients, coliforms and pollutants (Cunha et al., 2013).

For the TSI, the mesotrophic characteristic of the sites under evaluation may have resulted from natural eutrophy and anthropic activities. Few studies have been performed using this index in Rio Grande do Sul, and they are mainly focussed on the evaluation of lakes (Schäfer, 1988; Cunha et al., 2013). According to Fia et al. (2009), trophic state indices describe the effect of human activities in river basins, in addition to aiding in the development of handling and management plans for aquatic ecosystem using strategies to promote the sustainability of water resources.

\subsection{RAP}

The rapid assessment protocol (RAP) is applied based on the score of parameters (1-9) that assess the characteristics of the sections and the environmental impacts that result from anthropic activities, according to Callisto et al. (2002), whereas the parameters (10-15) adapted from Hannaford et al. (1997) indicate habitat conditions and the levels of conservation of natural characteristics. Therefore, the final RAP score for the areas along the stream sources is a marker of natural environmental conditions, a characteristic that is identical to that described by Vargas and FerreiraJunior (2012) for stream sources in the study of two micro basins of the Gandu River in the municipality of Afonso Cláudio, state of Espírito Santo, Brazil.

The parameter of anthropic alterations is directly associated with the use of the area. For example, the site of the Pampa stream is frequently visited in hotter periods because it has a water fall used for recreational purposes by the local population. In the site of the Schmidt stream, the presence of houses where domestic wastewaters are not treated is the main focus of anthropic changes. The stability of margins is directly associated with the length of the area of riparian vegetation, as found in the site of the EstânciaVelha/Portão stream, where part of the riparian vegetation of one of the margins was removed leading to instability followed by erosion and lixiviation of the soil, high degrees of turbidity, (particularly in periods with high rainfall rates) and extensive mud deposition on the bottom of the water body, which explains the degree of turbidity, which is above the standard for Class 1 waters. Natural vegetation in the stream sources, according to Donadio et al. (2005), ensures a better water quality than in places where anthropogenic activities such as agriculture are predominant.

\subsection{Tradescantia bioassay}

The frequencies of micronuclei obtained evidenced the water genotoxicity along the sources of two of the streams sampled at one of the exposure times. Only the water of the Schmidt stream presented no genotoxicity in either sampling period. The results corroborate those reported by Umbuzeiro et al. (2007) for the genotoxicity of a tributary of the Cristais River in the metropolitan area of São Paulo, where 1.8 micronuclei were observed in Tradescantia pallida var. purpurea inflorescences.
Although the values of the physical and chemical parameters measured for the water of the streams under study were, in general, below the limits defined in legislation, not investigated genotoxic substances, as well as mutagenic chemical combinations, may contribute to the increase of micronuclei frequency. Of the metals analyzed, Fe presented concentrations above the standard for Class 1 water (Brasil, 2005), and its effect on the formation of micronuclei in Tradescantia pallida var. purpurea should be further investigated.

In the first exposure, the EstânciaVelha/Portão stream showed a significantly elevated genotoxic potential, which reinforced the reports of high pollutant concentrations and toxicity of this water body to Daphnia similis (Claus, 1879), Daphnia magna, Ceriodaphnia dubia (Richard, 1894) and Hyalella azteca (Saussure, 1858) reported by Mitteregger-Júnior et al. (2007). However, in the second sampling, micronuclei frequency was significantly lower than in the first sampling. This may have occurred due to the accumulation of rainfall in the four days before sample collection in the streams, which was greater in the second exposure. The responses of biomarkers are influenced by changes in abiotic factors (Handy et al., 2003). Rainfall periods, such as on the days before the second water sampling from the EstânciaVelha/Portão stream, seems to reduce the concentration of pollutants and, therefore, relatively minimising genetic damage to Tradescantia pallida var. purpurea, as reported by Thewes et al. (2011) in a study conducted in sewage treatment plants. Vilches (2009) observed a decrease in the genotoxic potential of the water of the Cadeia stream in the Caí River basin, Brazil, in assays using erythrocytes of the Astuyanax jacuhiensis fish (Cope, 1894) during one of the sampling months, and assigned that finding to the constant rainfall before the sampling day.

The data reinforce the importance of the Tradescantia pallida var. purpurea micronuclei assay as a sensitive parameter of environmental pollution of the water bodies that are part of the Sinos River basin. It is a simple, efficient and rapid bioassay (Steinkellner et al., 1999) that may warn about the real conditions of water quality (Yang, 1999) and the potential genotoxic risks to biota.

\section{Final Considerations}

The interpretation of data from integrated evaluation assessments is extremely complex, due to the diversity of variables that act upon the environment directly or indirectly. Isolated parameters would not allow a characterisation of the environmental scenario as through has the one obtained in this study through an integrated assessment.

Anthropic alterations, such as the discharge of domestic wastewaters, are factors directly or indirectly responsible for the legal classification of waters as Class 3 or 4 at the sampling sites. Contrary, the results of the RAP demonstrated a better environmental quality. It is known that the measurements of physical and chemical water parameters are punctual, reflecting the exact time 
of sampling. On the other hand, PAR includes qualitative indicators of the water and surroundings of the water body, reflecting the history of the conservation status of the area.

Of the chemical parameters evaluated, Fe presented concentrations above those established in legislation in the three sites sampled, which may contribute to the genotoxicity of waters in the sites of the EstânciaVelha/ Portão and Pampa streams. Increased risks of genetic damage to organisms due to heavy metals are known, and further studies should investigate the genotoxic potential of $\mathrm{Fe}$ in particular.

\section{Acknowledgements}

The authors wish to thank the Universidade Feevale for the use of the laboratories, financial support and the grant awarded to C. T. Petry; the Ministério da Ciência e Tecnologia/Financiadora de Estudos e Projetos for financial support (MCT/FINEP, Process 551923/2011-3); the Conselho Nacional de Desenvolvimento Científico e Tecnológico (CNPq) for the grants (DTI-B) awarded to T. Benvenuti and M. A. Kieling-Rubio; the Coordenação de Aperfeiçoamento de Pessoal de Nivel Superior (CAPES) for the grant awarded to G. M. da Costa and D. Endres Júnior for editing the figure.

\section{References}

ALVES, ICC., EL-ROBRINI, M., SANTOS, MLS., MONTEIRO, SM., BARBOSA, LPF. and GUIMARÃES, JTF., 2012. Qualidade das águas superficiais e avaliação do estado trófico do Rio Arari (Ilha de Marajó, norte do Brasil). Acta Amazonica, vol. 42, no. 1, p. 115-124. http://dx.doi.org/10.1590/S0044-59672012000100014.

American Public Health Association - APHA, 2005. Standard methods for the examination of water and wastewater. 21 st ed. Washington: APHA. $1220 \mathrm{p}$.

Associação Brasileira de Normas Técnicas - ABNT, 1987. ABNT NBR 9898: 1987 - Preservação e técnicas de amostragem de efluentes líquidos e corpos receptores. Rio de Janeiro: ABNT.

Brasil. Código Florestal, 1965. Lei $n^{\circ} 4771 / 1965$, de 15 de setembro de 1965. Diário Oficial da União, Brasília, 16 set. Available from: $<$ http://www.planalto.gov.br/Ccivil_03/LEIS/ L4771.htm>. Access in: 10 Mar. 2013.

Brasil. Conselho Nacional do Meio Ambiente, 2005. Resolução $n^{\circ} 357$ de 17 de março de 2005. Dispõe sobre a classificação dos corpos de água e diretrizes ambientais para o seu enquadramento, bem como estabelece as condições e padrões de lançamento de efluentes, e dá outras providências. Diário Oficial da União, Brasília, 18 mar. Available from: <http://www.mma.gov.br/ port/conama/res/res05/res35705.pdf>. Access in: 10 Nov. 2012.

Brasil. Agência Nacional de Águas - ANA, 2012. Portal da qualidade das águas. ANA. Available from: $<16$ set. Available from: <http://portalpnqa.ana.gov.br/pnqa.aspx $>$. Access in: 15 Dez. 2012.

BURIOL, GA., ESTEFANEL, V., CHAGAS, AC. and EBERHARDT. D., 2007. Clima e vegetação natural do Rio Grande do Sul segundo o diagrama climático de Walter e Lieth. Ciência Florestal, vol. 17, p. $91-100$.
CALLISTO, M., FERREIRA, WR., MORENO, P., GOULART, M. and PETRUCIO, M., 2002. Aplicação de um protocolo de avaliação rápida da diversidade de habitats em atividades de ensino e pesquisa (MG-RJ). Acta Limnologica Brasiliensia, vol. 14, no. 1, p. 91-98.

Comitê da Bacia Hidrográfica do Rio dos Sinos-COMITESINOS, 2012. Comitê da Bacia Hidrográfica do Rio dos Sinos, COMITESINOS. Available from: $<$ http://www.comitesinos.com. br/>. Access in: 10 Dez. 2012.

CUNHA, RW., GARCIA JUNIOR, MDN., ALBERTONI, EF. and PALMA-SILVA, C., 2013. Qualidade de água de uma lagoa rasa em meio rural no sul do Brasil. Revista Brasileira de Engenharia Agrícola e Ambiental, vol. 17, no. 7, p. 770-779. http://dx.doi. org/10.1590/S1415-43662013000700012.

DONADIO, AC., GALBIATTI, JA. and PAULA, RC., 2005. Qualidade da água de nascentes com diferentes usos do solo na bacia hidrográfica do Córrego Rico, São Paulo, Brasil. Engenharia Agrícola, vol. 25, no. 1, p. 115-125. http://dx.doi.org/10.1590/ S0100-69162005000100013.

DUAN, CQ., HU, B., WANG, ZH., WEN, CH., YAN, SQ., JIANG, XH., WANG, DK., LI, Q. and LIANG, XF., 1999. Tradescantia bioassays for the determination of genotoxicity of water in the Panlong River, Kunming, People's Republic of China. Mutation Research, vol. 426, no. 2, p. 127-131. PMid:10350584.

Environmental Protection Agency - EPA, 1987. Biological criteria for the protection of aquatic life. Columbus: Division of water Quality Monitoring and Assessment. vol. 1-3.

FEIDEN, IR. and TERRA, NR., 2009. Ecotoxicological evaluation of sediment from a river contaminated by industrial effluents, Sinos River (Rio Grande do Sul, Brazil) using Daphnia magna (Straus, 1820). Acta Limnologica Brasiliensia, vol. 21, no. 4, p. 441-450.

FIA, R., MATOS, AT., CORADI, PC. and PEREIRA-RAMIREZ, O., 2009. Estado trófico da água na Bacia Hidrográfica da Lagoa Mirim, RS, Brasil. Revista Ambiente e Água, vol. 4, no. 1, p. 132-141. http://dx.doi.org/10.4136/ambi-agua.78.

FIGUEIREDO, JAS., DRUMM, E., RODRIGUES, MAS. and SPILKI, FR., 2010. The Rio dos Sinos watershed: an economic and social space and its interface with environmental status. Brazilian Journal of Biology $=$ Revista Brasileira de Biologia, vol. 70, supplement 4, p. 1131-1136. PMid:21225153.

Fundação Estadual de Proteção Ambiental -FEPAM, 2012. Qualidade ambiental - região hidrográfica do Guaiba. FEPAM. Available from: <http://www.fepam.rs.gov.br/qualidade/qualidade_sinos/ sinos.asp>. Access in: 10 Dez. 2012.

GRISOLIA, CK. and STARLING, FLRM., 2001. Micronuclei monitoring of fishes from Lake Paranoá, under influence of sewage treatment plant discharges. Mutation Research, vol. 491, no. 1-2, p. 39-44. http://dx.doi.org/10.1016/S1383-5718(00)00168-6. PMid:11287296

HANDY, RD., GALLOWAY, TS. and DEPLEDGE, MH., 2003. A proposal for the use of biomarkers for the assessment of chronic pollution and in regulatory toxicology. Ecotoxicology, vol. 12, no. 1-4, p. 331-343. http://dx.doi.org/10.1023/A:1022527432252. PMid:12739879

HANNAFORD, MJ., BARBOUR, MT. and RESH, VH., 1997. Training reduces observer variability in visual-based assessments of stream habitat. Journal of the North American Benthological Society, vol. 16, no. 4, p. 853-860. http://dx.doi.org/10.2307/1468176. 
Instituto Brasileiro de Geografia e Estatística - IBGE, 2012. Cidades@. IBGE. Available from: <http://cidades.ibge.gov.br/ painel/painel.php?codmun=431340>. Access in: 10 Jan.2012.

Instituto Mineiro de Gestão das Águas - IGAM, 2004. Relatório de monitoramento das águas superficiais na Bacia do Rio São Francisco em 2003: Sub-Bacia do Rio Paraopeba / Instituto Mineiro de Gestão das Águas. Belo Horizonte: IGAM. 197 p.

KARR, J. and CHU, EW., 1999. Restoring life in running waters: better biological monitoring. Washington: Inland Press. 220 p.

LAMPARELLI, MC., 2004. Grau de trofia em corpos d'água do estado de São Paulo: avaliação dos métodos de monitoramento. São Paulo: Instituto de Biociências, Universidade de São Paulo. 238 p. Doctoral thesis.

LUÍZ, AME., PINTO, MLC. and SCHEFFER, EWO., 2012. Parâmetros de cor e turbidez relacionados aos usos do solo e a morfometria da bacia hidrográfica do Rio Taquaral, São Mateus do Sul - PR. Caminhos de Geografia, vol. 13, no. 41, p. 52-67.

MERLO, C., ABRIL, A., AMÉ, MV., ARGÜEllo, GA., CARRERAS, HA., CHIAPPERO, MS., HUED, AC., WANNAZ, E., GALANTI, LN., MONFERRÁN, MV., GONZÁLEZ, CM. and SOLÍS, VM., 2011. Integral assessment of pollution in the Suquía River (Córdoba, Argentina) as a contribution to lotic ecosystem restoration programs. The Science of the Total Environment, vol. 409, no. 23, p. 5034-5045. http://dx.doi.org/10.1016/j. scitotenv.2011.08.037. PMid:21925711

MIELLI, AC., MATTA, MEM., NERSESYAN, A., SALDIVA, PHN. and UMBUZEIRO, GA., 2009. Evaluation of the genotoxicity of treated urban sludge in the Tradescantia micronucleus assay. Mutation Research, vol. 672, no. 1, p. 51-54. http://dx.doi. org/10.1016/j.mrgentox.2008.09.007. PMid:18940264

MITTEREGGER JÚNIOR, H., SILVA, J., ARENZON, A., PORTELA, CS., FERREIRA, ICF. and HENRIQUES, JAP., 2007. Evaluation of genotoxicity and toxicity of water and sediment samples from a Brazilian stream influenced by tannery industries. Chemosphere, vol. 67, no. 6, p. 1211-1217. http:// dx.doi.org/10.1016/j.chemosphere.2006.10.048. PMid:17157352

MORENO, JA., 1961. Clima do Rio Grande do Sul. Porto Alegre: Secretaria da Agricultura. $42 \mathrm{p}$.

NAIME, R. and FAGUNDES, RS., 2005. Controle da qualidade da água do Arroio Portão, RS. Pesquisa em Geociencias, vol. 32 , no. 1, p. 27-35.

NASCIMENTO, CA. and NAIME, R., 2009. Monitoramento de ph, temperatura, $\mathrm{OD}, \mathrm{DBO}$ e condições microbiológicas das águas do arroio Pampa em Novo Hamburgo (RS). Estudos Tecnológicos, vol. 5, no. 2, p. 227-244. http://dx.doi.org/10.4013/ete.2009.52.09.

RECHENMACHER, C., SIEBEL, AM., GOLDONI, A., KLAUCK, CR., SARTORI, T., RODRIGUES, MT., RODRIGUES, MA., GEHLEN, G., ARDENGHI, PG. and SILVA, LB., 2010. A multibiomarker approach in rats to assess the impact of pollution on Sinos River, Southern Brazil. Brazilian Journal of Biology $=$ Revista Brasileira de Biologia, vol. 70, no. 4, suplemento, p. 1223-1230. http://dx.doi.org/10.1590/S1519-69842010000600012. PMid:21225164

RODRIGUES, ASL. and CASTRO, PTA., 2008. Protocolos de avaliação rápida: instrumentos complementares no monitoramento dos recursos hídricos. Revista Brasileira de Recursos Hidricos, vol. 13, no. 1, p. 161-170.

SCALON, MCS., RECHENMACHER, C., SIEBEL, AM., KAYSER, ML., RODRIGUES, MT., MALUF, SW., RODRIGUES,
MAS. and SILVA, LB., 2010. Evaluation of Sinos River water genotoxicity using the comet assay in fish. Brazilian Journal of Biology $=$ Revista Brasileira de Biologia, vol. 70, supplement 4, p. 1217-1222. http://dx.doi.org/10.1590/S1519-69842010000600011. PMid:21225163

SCHÄFER, A., 1988. Tipificação ecológica de lagoas costeiras do Rio Grande do Sul. Acta Limnologica Brasiliensia, vol. 2, p. 29-55.

STEINKELLNER, H., KASSIE, F. and KNASMÜLLER, S., 1999. Tradescantia-micronucleus assay for the assessment of the clastogenicity of Austrian water. Mutation Research, vol. 426, no. 2, p. 113-116. http://dx.doi.org/10.1016/S0027-5107(99)00051-2. PMid:10350581

STRECK, EV., KÄMPF, N., DALMOLIN, RSD., KLAMT, E., NASCIMENTO, PC., SCHNEIDER, P., GIASSON, E. and PINTO, LFS., 2008. Solos do Rio Grande do Sul. 2nd ed. Porto Alegre: EMATER/RS. 222 p.

TEIXEIRA, MB., COURA NETO, AB., PASTORE, U. and RANGEL FILHO, ALR., 1986. Levantamento de recursos naturais. In Instituto Brasileiro de Geografia e Estatística - IBGE (Ed.). Vegetação. As regiões fitoecológicas, sua natureza e seus recursos econômicos - estudo fitogeográfico. Rio de Janeiro: IBGE. vol. 33, p. 541-632.

TERNUS, RZ., SOUZA-FRANCO, GM., ANSELMINI, MEK., MOCELLIN, DJC. and DAL MAGRO, J., 2011. Influence of urbanisation on water quality in the basin of the upper Uruguay River in western Santa Catarina, Brazil. Acta Limnologica Brasiliensia, vol. 23, no. 2, p. 189-199. http://dx.doi.org/10.1590/ S2179-975X2011000200009.

THEWES, MR., ENDRES JUNIOR, D. and DROSTE, A., 2011. Genotoxicity biomonitoring of sewage in two municipal wastewater treatment plants using the Tradescantia pallida var. purpurea bioassay. Genetics and Molecular Biology, vol. 34, no. 4, p. 689-693. http://dx.doi.org/10.1590/S1415-47572011005000055. PMid:22215975

UMBUZEIRO, GA., COIMBRÃO, CA., KUMMROW, F., LOBO, DJA. and SALDIVA, PHN., 2007. Mutagenic activity assessment of Cristais River, São Paulo, Brazil, using the blue rayon / Salmonella microsome and the Tradescantia pallida micronuclei assays. Journal Brazilian Society Ecotoxicology, vol. 2, no. 2, p. 163-171. http://dx.doi.org/10.5132/jbse.2007.02.009.

VARGAS, JRA. and FERREIRA-JÚNIOR, PD., 2012. Aplicação de um protocolo de avaliação rápida na caracterização da qualidade ambiental de duas microbacias do Rio Guandu, Afonso Cláudio, ES. Revista Brasileira de Recursos Hidricos, vol. 17, p. 161-168.

VILCHES, M., 2009. Análise genotóxica do rio cadeia/RS através do ensaio cometa e teste de micronúcleo e anormalidades nucleares utilizando peixes como bioindicadores. Novo Hamburgo: Universidade Feevale. 59 p. Masters Dissertation in Environmental Quality. $<$ ths $>$.

WEBER, P., BEHR, ER., KNORR, CDL., VENDRUSCOLO, DS., FLORES, EMM., DRESSLER, VL. and BALDISSEROTO, B., 2013. Metals in the water, sediment and tissues of two fish species from different trophic levels in a subtropical Brazilian River. Microchemical Journal, vol. 106, p. 61-66. http://dx.doi. org/10.1016/j.microc.2012.05.004.

YANG, G., 1999. Tradescantia-micronucleus assay on the water quality of lake Hongzhe in Jiangsu Province, China. Mutation Research, vol. 426, no. 2, p. 155-157. http://dx.doi.org/10.1016/ S0027-5107(99)00060-3. PMid:10350590 